\title{
CELL DAMAGE, WATER STATUS AND GAS EXCHANGES IN CASTOR BEAN AS AFFECTED BY CATIONIC COMPOSITION OF WATER ${ }^{1}$
}

\author{
GEOVANI SOARES DE LIMA ${ }^{2 *}$, HANS RAJ GHEYI ${ }^{3}$, REGINALDO GOMES NOBRE ${ }^{4}$, LAURIANE ALMEIDA DOS \\ ANJOS SOARES ${ }^{2}$, JOÃO BATISTA DOS SANTOS
}

\begin{abstract}
Castor bean is an oilseed crop which is able to adapt to various edaphoclimatic conditions and has considerable contents of oil in its seeds, with potential for use in the castor oil industry. In this context, this study aimed to evaluate changes in membrane damage, water status and gas exchanges in castor bean plants (cv. 'BRS Energia') in response to irrigation water salinity and cationic composition. Randomized blocks were used to test six cationic compositions $\left(\mathrm{S}_{1}-\mathrm{Control} ; \mathrm{S}_{2}-\mathrm{Na}^{+} ; \mathrm{S}_{3}-\mathrm{Ca}^{2+} ; \mathrm{S}_{4}-\mathrm{Na}^{+}+\mathrm{Ca}^{2+} ; \mathrm{S}_{5}-\mathrm{K}^{+}\right.$and $\mathrm{S}_{6}-\mathrm{Na}^{+}+$ $\mathrm{Ca}^{2+}+\mathrm{Mg}^{2+}$ ), in four replicates. Plants in the control treatment were subjected to irrigation using water of low electrical conductivity $\left(\mathrm{S}_{1}-\mathrm{ECW}=0.6 \mathrm{dS} \mathrm{m} \mathrm{m}^{-1}\right)$, whereas those in the other treatments were irrigated using 4.5 $\mathrm{dS} \mathrm{m} \mathrm{m}^{-1}$ water prepared with different cations. Higher leaf succulence associated with lower water saturation deficit is an indication of tolerance to salt stress in castor bean plants irrigated with $\mathrm{K}^{+}$-rich water. The presence of $\mathrm{Na}^{+}$in irrigation water caused the highest water saturation deficit in castor bean leaf blades. The lowest damage in cell membranes was observed in plants irrigated with $\mathrm{Ca}^{2+}$-rich water. The damaging effect of salt stress on castor bean gas exchanges depends on the cationic composition of water and occurred in the following order: $\mathrm{Na}^{+}>\mathrm{Na}^{+}+\mathrm{Ca}^{2+}>\mathrm{Ca}^{2+}>\mathrm{Na}^{+}+\mathrm{Ca}^{2+}+\mathrm{Mg}^{2+}>\mathrm{K}^{+}$.
\end{abstract}

Keywords: Ricinus communis L. 'BRS Energia'. Salinity. Irrigation.

\section{DANO CELULAR, STATUS HÍDRICO E TROCAS GASOSAS NA MAMONEIRA SOB NATUREZA CATIÔNICA DA ÁGUA}

RESUMO - A mamoneira é uma oleaginosa que possui capacidade de adaptação a variadas condições edafoclimáticas, além de ser uma cultura que se apresenta com considerável teor de óleo em suas sementes com potencial para uso na indústria ricinoquímica. Neste contexto, o estudo teve como objetivo avaliar as mudanças do dano de membranas, o status hídrico e as trocas gasosas em plantas de mamoneira (cv. BRS Energia) em respostas a salinidade e natureza catiônica da água de irrigação. Utilizou-se de blocos casualizados, testando-se seis composições catiônicas da água $\left(\mathrm{S}_{1}-\mathrm{Testemunha} ; \mathrm{S}_{2}-\mathrm{Na}^{+} ; \mathrm{S}_{3}-\mathrm{Ca}^{2+} ; \mathrm{S}_{4}-\mathrm{Na}^{+}+\mathrm{Ca}^{2+} ; \mathrm{S}_{5}-\mathrm{K}^{+}\right.$e $\mathrm{S}_{6}-\mathrm{Na}^{+}+$ $\mathrm{Ca}^{2+}+\mathrm{Mg}^{2+}$ ) e quatro repetições. As plantas referentes ao tratamento testemunha foram submetidas à irrigação com água de baixa condutividade elétrica $\left(\mathrm{S}_{1}-\mathrm{CEa}=0,6 \mathrm{dS} \mathrm{m} \mathrm{m}^{-1}\right)$ e os demais tratamentos foram irrigadas com CEa de 4,5 $\mathrm{dS} \mathrm{m}^{-1}$ preparada com diferentes íons. A maior suculência no limbo foliar associado ao menor déficit de saturação hídrica é um indicativo de tolerância ao estresse salino da mamoneira irrigada com água de composição potássica. A presença de sódio na água de irrigação proporcionou o maior déficit de saturação hídrica no limbo foliar da mamoneira. O menor dano na membrana celular foi obtido nas plantas irrigadas com água de composição cálcica. $\mathrm{O}$ efeito deletério do estresse salino sobre as trocas gasosas da mamoneira depende da natureza catiônica da água e obedeceu à seguinte ordem $\mathrm{Na}^{+}>\mathrm{Na}^{+}+\mathrm{Ca}^{2+}>\mathrm{Ca}^{2+}>\mathrm{Na}^{+}+\mathrm{Ca}^{2+}+\mathrm{Mg}^{2+}>\mathrm{K}^{+}$.

Palavras-chave: Ricinnus communis L. BRS Energia. Salinidade. Irrigação.

\footnotetext{
${ }^{*}$ Corresponding author

${ }^{1}$ Received for publication in $11 / 09 / 2017$; accepted in $02 / 11 / 2019$

Paper extracted from the postdoctoral research of the first author.

${ }^{2}$ Academic Unit of Agricultural Sciences, Center of Agrifood Science and Technology, Universidade Federal de Campina Grande, Pombal, PB, Brazil; geovani.soares@pq.cnpq.br - ORCID: 0000-0001-9960-1858, lauriane.soares@pq.cnpq.br - ORCID: 0000-0002-7689-9628.

${ }^{3}$ Nucleus of Soil and Water Engineering, Universidade Federal do Recôncavo da Bahia, Cruz das Almas, BA, Brazil; hans@pq.cnpq.br ORCID: 0000-0002-1066-0315.

${ }^{4}$ Department of Science and Technology, Universidade Federal Rural do Semi-Árido, Caraúbas, RN, Brazil; rgomesnobre@yahoo.com.br ORCID: 0000-0002-6429-1527.

${ }^{5}$ Rural Technology and Health Center, Universidade Federal de Campina Grande, Patos, PB, Brazil; agrosantos@hotmail.com - ORCID: 0000-0003-3058-007X.
} 


\section{INTRODUCTION}

Castor bean (Ricinus communis L.) is an oilseed crop with potential for economic exploitation in the Brazilian northeastern semi-arid region, due to its rusticity, adaptation to adverse climate and soil conditions, fast growth, high production and various possible applications of its products and byproducts in the castor oil industry and agriculture (SILVA et al., 2009b), which are used in the production of paints, cosmetics, soaps, varnishes, adhesives, fungicides, insecticides and even prostheses and implants (RODRIGUES et al., 2009).

Brazilian castor bean production in the $2017 / 2018$ season was 16.2 thousand tons of grains, with an average yield of $478 \mathrm{~kg} \mathrm{ha}^{-1}$ in 33.9 thousand hectares of planted area. In this season, the northeast region was responsible for 14.7 thousand tons of grains, with a yield of $456 \mathrm{~kg} \mathrm{ha}^{-1}$ in a cultivated area of approximately 32.2 thousand hectares. Among the states with the highest production, Bahia stood out in the first position, with a production of 13.5 thousand tons and a yield of $499 \mathrm{~kg} \mathrm{ha}^{-1}$ in an area of 27.1 thousand hectares. Ceará had the second highest production in the country, with 1.1 thousand tons and a yield of $217 \mathrm{~kg} \mathrm{ha}^{-1}$ in a planted area of 4.9 thousand hectares, while Piauí was in third position (CONAB, 2018).

Despite its importance, cultivated areas especially in the Brazilian northeastern semi-arid region are subject to agro-climatic variations with common occurrence of high temperatures, high rainfall levels, irregular rainfall distribution and high evapotranspiration rates in most of the year, all contributing to the scarcity of surface waters (NOBRE et al., 2011). In this region, the salt concentrations in water which affect plant growth and development vary and the effects on crops depend, among other factors, on both the total concentration and ionic composition of irrigation water.

The presence of ions, depending on the salt and genotype and/or species, besides affecting water availability, causes alterations in osmotic potential, ionic toxicity and imbalance in nutrient absorption, causing an overall reduction of growth, with serious losses in agricultural production (AHMED; MONTANI, 2010). The osmotic and specific effects of ions may alter the stability of cell membranes and increase their permeability, affecting the physiological and biochemical functions of plants, which leads to disorders in water relations, alterations in water absorption and the use of essential nutrients, besides the accumulation of toxic ions in chloroplasts, limiting photosynthesis due to partial stomatal closure, and resulting in damage to the photosynthetic apparatus and/or to the enzymatic system of $\mathrm{CO}_{2}$ fixation, regardless of the nature of the salts (NEVES et al., 2009; SILVA et al., 2014; LIMA et al., 2015a).
Some studies have highlighted the deleterious effects caused by salt stress on castor bean, classifying this crop as moderately sensitive to salinity (AYRES; WESTCOT, 1999; SOARES et al., 2012; ALVES et al., 2012; NOBRE et al., 2013; SANTOS et al., 2013; LIMA et al., 2015a), but these are limited to evaluating only the use of water with different levels of salinity. New studies are necessary, especially to assess the effects of irrigation using waters of different cationic compositions on the castor bean crop, cultivar 'BRS Energia'.

In this context, the present study aimed to evaluate the cell damage, water status and gas exchanges of castor bean cv. 'BRS Energia', as a function of irrigation with saline water and cationic composition.

\section{MATERIAL AND METHODS}

The experiment was carried out in drainage lysimeters under greenhouse conditions at the Center of Technology and Natural Resources of the Federal University of Campina Grande (CTRN/UFCG), located in the municipality of Campina Grande, PB, situated at the local geographic coordinates $7^{\circ} 15^{\prime} 18^{\prime}, \mathrm{S}, 35^{\circ} 52^{\prime} 28^{\prime}, \mathrm{W}$ and mean altitude of $550 \mathrm{~m}$.

Treatments consisted of six types of irrigation water salinity $\left(\mathrm{S}_{1}-\mathrm{Control} ; \mathrm{S}_{2}-\mathrm{Na}^{+} ; \mathrm{S}_{3}-\mathrm{Ca}^{2+} ; \mathrm{S}_{4}-\right.$ $\mathrm{Na}^{+}+\mathrm{Ca}^{2+} ; \mathrm{S}_{5}-\mathrm{K}^{+}$and $\mathrm{S}_{6}-\mathrm{Na}^{+}+\mathrm{Ca}^{2+}+\mathrm{Mg}^{2+}$ ), so as to have equivalent proportions of $1: 1$ for $\mathrm{Na}: \mathrm{Ca}$ and 7:2:1 for $\mathrm{Na}^{+}+\mathrm{Ca}^{2+}+\mathrm{Mg}^{2+}$, respectively. Plants in the control treatment $\left(\mathrm{S}_{1}\right)$ were irrigated using water with an electrical conductivity (ECw) of $0.6 \mathrm{dS} \mathrm{m}{ }^{-1}$, whereas those subjected to the other types of water salinity $\left(\mathrm{S}_{2} ; \mathrm{S}_{3} ; \mathrm{S}_{4} ; \mathrm{S}_{5}\right.$ and $\left.\mathrm{S}_{6}\right)$ were irrigated using $4.5 \mathrm{dS} \mathrm{m}^{-1}$ water, prepared with different cations, all in the form of chloride. The experiment was set up in a randomized block design with six treatments and four replicates, totaling 24 experimental plots, in each of which five plants were evaluated.

The cultivar 'BRS Energia' was used in the experiment because it is a vigorous genetic material, which is precocious (cycle from 120 to 150 days), short, with semi-dehiscent fruits, oil content around $48 \%$ in its seeds, and a mean yield of $1,800 \mathrm{~kg} \mathrm{ha}^{-1}$ (SILVA et al., 2009b).

Plants were grown in drainage lysimeters with a $100 \mathrm{~L}$ capacity (height of $50 \mathrm{~cm}$, base diameter of $30 \mathrm{~cm}$ and upper opening diameter of $33 \mathrm{~cm}$ ) perforated at the bottom to allow drainage and attached to a 4-mm diameter drain. The tip of the drain inside the lysimeter was wrapped in nonwoven geotextile (Bidim OP 30) and a plastic container was placed below each drain to collect the drained water.

The lysimeters were filled with a $2-\mathrm{kg}$ layer of crushed stone (zero size) followed by $54 \mathrm{~kg}$ of soil material (properly pounded to break up clods and 
homogenized), plus $76 \mathrm{~kg}$ of the same soil, plus 1.70 $\mathrm{kg}$ of earthworm humus in each lysimeter to achieve $1 \%$ organic matter based on the total weight. To facilitate irrigation, the upper $10 \mathrm{~cm}$ of the lysimeters were not filled. The soil used in the study was collected in the $0-30 \mathrm{~cm}$ layer (A horizon) of an
Argissolo Acinzentado Eutrófico from the district of São José da Mata (Campina Grande, PB). Before the experiment, the soil was sampled to determine its chemical and physical characteristics (Table 1), according to the methodologies proposed by Claessen (1997).

Table 1. Chemical and physical characteristics of the soil used in the experiment, before applying the treatments.

\begin{tabular}{|c|c|c|c|c|c|c|c|c|c|}
\hline \multicolumn{10}{|c|}{ Chemical characteristics } \\
\hline \multirow{2}{*}{$\begin{array}{c}\mathrm{pH}\left(\mathrm{H}_{2} \mathrm{O}\right) \\
(1: 2.5)\end{array}$} & \multirow{2}{*}{$\begin{array}{c}\mathrm{OM} \\
\text { dag kg }\end{array}$} & \multirow{2}{*}{$\begin{array}{c}\mathrm{P} \\
\left(\mathrm{mg} \mathrm{kg}^{-1}\right)\end{array}$} & $\mathrm{K}^{+}$ & $\mathrm{Na}^{+}$ & $\mathrm{Ca}^{2+}$ & $\mathrm{Mg}^{2+}$ & $\mathrm{Al}^{3+}$ & $\mathrm{H}^{+}$ & \multirow{2}{*}{$\begin{array}{c}\mathrm{EC}_{\mathrm{se}} \\
\left(\mathrm{dS} \mathrm{m}^{-1}\right)\end{array}$} \\
\hline & & & \multicolumn{6}{|c|}{$\ldots\left(\mathrm{cmol}_{\mathrm{c}} \mathrm{kg}^{-1}\right) .}$. & \\
\hline 5.13 & 0.34 & 20.09 & 0.07 & 0.05 & 0.40 & 1.30 & 0.04 & 1.74 & 0.16 \\
\hline \multicolumn{10}{|c|}{ Physical characteristics } \\
\hline \multicolumn{3}{|c|}{ Size fraction $\left(\mathrm{g} \mathrm{kg}^{-1}\right)$} & & \multicolumn{2}{|c|}{ Water content $(\mathrm{kPa})$} & AW & Total & RD & PD \\
\hline \multirow{2}{*}{ Sand } & \multirow{2}{*}{ Silt } & \multirow{2}{*}{ Clay } & class & 33.42 & 1519.5 & & porosity & טעם & 舟 \\
\hline & & & & (................ & $\left(\right.$ dag kg $\left.^{-1}\right)$ & (............. & & \multicolumn{2}{|c|}{$\left(\mathrm{kg} \mathrm{dm}^{-3}\right)$} \\
\hline 856.10 & 110.70 & 33.20 & SL & 6.72 & 1.62 & 5.10 & 0.49 & 1.54 & 2.72 \\
\hline
\end{tabular}

Based on soil analysis data, soil acidity was corrected by adding $49.25 \mathrm{~g}$ of dolomitic limestone to the soil of each lysimeter (130 kg of soil), the quantity required to neutralize $\mathrm{Al}^{3+}$ and increase the contents of $\mathrm{Ca}^{2+}$ and $\mathrm{Mg}^{2+}$ by $70 \%$ in the exchange complex. After acidity correction, the soil had the following chemical characteristics: $\mathrm{Ca}^{2+}=1.14 \mathrm{cmol}_{\mathrm{c}}$ $\mathrm{kg}^{-1} ; \mathrm{Mg}^{2+}=1.36 \mathrm{cmol}_{\mathrm{c}} \mathrm{kg}^{-1} ; \mathrm{Na}^{+}=0.30 \mathrm{cmol}_{\mathrm{c}} \mathrm{kg}^{-1}$; $\mathrm{K}^{+}=0.14 \mathrm{cmol}_{\mathrm{c}} \mathrm{kg}^{-1} ; \mathrm{H}^{+}=0.11 \mathrm{cmol}_{\mathrm{c}} \mathrm{kg}^{-1} ; \mathrm{Al}^{3+}=0$ $\mathrm{cmol}_{\mathrm{c}} \mathrm{kg}^{-1} ; \mathrm{CEC}=3.05 \mathrm{cmol}_{\mathrm{c}} \mathrm{kg}^{-1}$; organic matter $=$ 1.08 dag kg ${ }^{-1} ; \mathrm{P}=47.80 \mathrm{mg} \mathrm{kg}^{-1}$ and $\mathrm{pH}$ in water $(1: 2.5)=6.42$.

Water salinity levels were obtained by dissolving sodium chloride $(\mathrm{NaCl})$, calcium chloride $\left(\mathrm{CaCl}_{2} \cdot 2 \mathrm{H}_{2} \mathrm{O}\right)$, magnesium chloride $\left(\mathrm{MgCl}_{2} \cdot 6 \mathrm{H}_{2} \mathrm{O}\right)$ and potassium chloride $(\mathrm{KCl})$ in irrigation water according to the preestablished treatments, using water from the local supply system. The quantity of salts to be added was determined based on the equation of Richards (1954), considering the relationship between $\mathrm{ECW}$ and the concentration of salts $\left(10^{*} \mathrm{mmol}_{\mathrm{c}} \mathrm{L}^{-1}=1 \mathrm{dS} \mathrm{m}^{-1}\right)$.

Prior to sowing, the water volume necessary to bring the soil to field capacity was determined using the method of saturation by capillarity followed by drainage. After the soil was brought to field capacity, using the respective waters of each treatment, 10 seeds of castor bean cv. 'BRS Energia' were planted in each lysimeter, at $2 \mathrm{~cm}$ depth, equidistantly distributed. At 10 days after sowing (DAS), thinning was performed to leave only one plant per pot.

The soil was maintained at field capacity by daily irrigations, applying in each lysimeter the waters corresponding to each treatment. The volume to be applied was determined according to the water requirement of castor bean plants, estimated by water balance: water volume applied minus water volume drained in the previous irrigation, plus a leaching fraction of 0.10 , according to previous studies (NOBRE et al., 2013).

Fertilization with nitrogen, potassium and phosphorus was carried out based on the recommendations of Novais, Neves and Barros (1991). Potassium nitrate $(40.62 \mathrm{~g})$ and monoammonium phosphate $(75 \mathrm{~g})$, corresponding to 100,150 and $300 \mathrm{mg} \mathrm{kg}^{-1}$ of soil of $\mathrm{N}, \mathrm{K}_{2} \mathrm{O}$ and $\mathrm{P}_{2} \mathrm{O}_{5}$, respectively, were applied as top-dressing in four portions through fertigation, at 10-day intervals, with the first application at 15 days after sowing (DAS). To meet probable deficiencies of micronutrients, castor bean leaves were sprayed at 30 and 60 DAS with $7 \mathrm{~L}$ of a solution containing $2.5 \mathrm{~g}$ $\mathrm{L}^{-1}$ of Ubyfol [(N (15\%); $\mathrm{P}_{2} \mathrm{O}_{5}(15 \%) ; \mathrm{K}_{2} \mathrm{O}(15 \%)$; $\mathrm{Ca}(1 \%) ; \mathrm{Mg}(1.4 \%) ; \mathrm{S}(2.7 \%) ; \mathrm{Zn}(0.5 \%) ; \mathrm{B}$ $(0.05 \%)$; Fe (0.5\%); Mn (0.05\%); Cu (0.5\%); Mo $(0.02 \%)]$

Phytosanitary management consisted of manual weeding every week, superficial soil scarification before each irrigation event and staking plants after flowering to avoid lodging. In addition, insecticides of the Neonicotinoid chemical group, fungicide of the Triazole chemical group and acaricide of the Abamectin chemical group were applied at doses of 5.4, 7.0 and $3.5 \mathrm{~g} \mathrm{~L}^{-1}$, respectively.

The effects of the different treatments on the castor bean crop were assessed at 90 DAS, the stage of fruit maturity, based on the determination of the percentage of cell membrane damage $(\% \mathrm{D})$, water saturation deficit (WSD), leaf succulence (SUC), stomatal conductance $(g s)$, transpiration $(E), \mathrm{CO}_{2}$ assimilation rate $(A)$, intercellular $\mathrm{CO}_{2}$ concentration $(\mathrm{C} i)$, instantaneous carboxylation efficiency (CEi) 
and intrinsic water use efficiency (WUEi).

Stomatal conductance (mol $\left.\mathrm{H}_{2} \mathrm{O} \mathrm{m}^{-2} \mathrm{~s}^{-1}\right)$, transpiration $\left(\mathrm{mmol} \mathrm{H} \mathrm{H}_{2} \mathrm{O} \mathrm{m}^{-2} \mathrm{~s}^{-1}\right), \mathrm{CO}_{2}$ assimilation rate $\left(\mu \mathrm{mol} \mathrm{m} \mathrm{m}^{-2} \mathrm{~s}^{-1}\right)$ and intercellular $\mathrm{CO}_{2}$ concentration $\left(\mu \mathrm{mol} \mathrm{m} \mathrm{m}^{-2} \mathrm{~s}^{-1}\right.$ ) were evaluated in the third leaf counted from the apex, using the portable photosynthesis meter "LCPro + " from ADC BioScientific Ltd. These data were used to determine WUEi (A/E) $\left[\left(\mu \mathrm{mol} \mathrm{m} \mathrm{m}^{-1} \mathrm{~s}^{-1}\right)\left(\mathrm{mol} \mathrm{H}_{2} \mathrm{O} \mathrm{m}^{-2} \mathrm{~s}^{-1}\right)^{-1}\right]$ and $\mathrm{CEi}(\mathrm{A} / \mathrm{Ci})\left[\left(\mu \mathrm{mol} \mathrm{m} \mathrm{m}^{-2} \mathrm{~s}^{-1}\right)\left(\mu \mathrm{mol} \mathrm{mol}{ }^{-1}\right]^{-1}\right.$.

To determine the percentage of cell membrane damage $(\% \mathrm{D}), 10$ discs with areas of 113 $\mathrm{mm}^{2}$ were collected in the third leaf from the apex, washed in distilled water to remove other electrolytes adhered to the leaves, placed in beakers containing $50 \mathrm{~mL}$ of double distilled water and hermetically closed with aluminum foil. The beakers were kept at a temperature of $25{ }^{\circ} \mathrm{C}$ for 90 minutes for the measurement of initial electrical conductivity (ECi) and then taken to a forced air ventilation oven at a temperature of $80^{\circ} \mathrm{C}$ for 90 minutes, when the final electrical conductivity (ECf) was measured. The percentage of cell membrane damage was obtained according to Scotti-Campos et al. (2013), using Eq. 1:

$$
\% \mathrm{D}=\frac{\mathrm{ECi}}{\mathrm{ECf}} \mathrm{x} 100
$$

where:

$\% \mathrm{D}=$ percentage of cell membrane damage;

$\mathrm{ECi}=$ initial electrical conductivity $\left(\mathrm{dS} \mathrm{m}^{-1}\right)$;

$\mathrm{ECf}=$ final electrical conductivity $\left(\mathrm{dS} \mathrm{m}^{-1}\right)$.

Water saturation deficit was quantified by collecting 3 fully expanded leaves from the upper third part of the plant, with samples of each plant, and determining the fresh mass (FM) of each one. These leaves were immediately weighed to avoid moisture losses, obtaining the values of fresh mass (FM), and then these samples were placed in plastic bags, immersed in distilled water and stored for 24 hours. After this period, excess water was removed with a paper towel to obtain the turgid mass (TM) of the samples, which were taken to an oven (temperature $\approx 65^{\circ} \mathrm{C} \pm 3{ }^{\circ} \mathrm{C}$, until constant weight) to obtain the dry mass (DM). Water saturation deficit was determined using the methodology described by Lima et al. (2015b), according to Eq. 2:

$$
\operatorname{WSD}(\%)=\frac{(\mathrm{TM}-\mathrm{FM})}{(\mathrm{TM}-\mathrm{DM})} \times 100
$$

where:

WSD $=$ water saturation deficit $(\%)$;

$\mathrm{FM}=$ leaf fresh mass $(\mathrm{g})$;

$\mathrm{TM}=$ leaf turgid mass $(\mathrm{g})$;

$\mathrm{DM}=$ leaf dry mass $(\mathrm{g})$.

Leaf succulence was determined according to the relationship proposed by Mantovani (1999): [(fresh phytomass - dry phytomass)/leaf area].

The obtained data were subjected to analysis of variance by the F test; when significant, means were compared and the contrasts between treatment means were defined (Tukey test at 0.05 probability level), using the statistical program SISVAR-ESAL (FERREIRA, 2011). The contrasts were defined as follows: $\hat{\mathrm{y}}_{1}\left(\mathrm{~S}_{1}\right.$ vs $\left.\mathrm{S}_{2} ; \mathrm{S}_{3} ; \mathrm{S}_{4} ; \mathrm{S}_{5} ; \mathrm{S}_{6}\right) ; \hat{\mathrm{y}}_{2}\left(\mathrm{~S}_{2} v s \mathrm{~S}_{3}\right) ; \hat{\mathrm{y}}_{3}$ $\left(\mathrm{S}_{2} v s \mathrm{~S}_{6}\right) ; \hat{y}_{4}\left(\mathrm{~S}_{2} v s \mathrm{~S}_{5}\right) ; \hat{y}_{5}\left(\mathrm{~S}_{5} v s \mathrm{~S}_{2} ; \mathrm{S}_{3} ; \mathrm{S}_{4} ; \mathrm{S}_{6}\right)$. For comparison between treatments, the respective standard deviation of each mean was calculated.

\section{RESULTS AND DISCUSSION}

According to the summary of analysis of variance (Table 2), the cationic composition of irrigation water significantly affected $(p<0.01)$ water saturation deficit in the leaf blade (WSD), cell membrane damage $(\% \mathrm{D}) \quad(\mathrm{p}<0.05)$ and leaf succulence (SUC) in castor bean cv. 'BRS Energia' at 90 days after sowing.

Table 2. Summary of analysis of variance for water saturation deficit in the leaf blade (WSD), cell membrane damage (\% D) and leaf succulence (SUC) in castor bean cv. 'BRS Energia', irrigated with waters of different cationic compositions, at 90 days after sowing.

\begin{tabular}{ccccc}
\hline \multirow{2}{*}{ VS/Contrasts } & \multirow{2}{*}{ DF } & \multicolumn{3}{c}{ Mean square } \\
\cline { 3 - 5 } & & WSD & $\% \mathrm{D}$ & SUC \\
\hline Blocks & 3 & $5.03^{\text {ns }}$ & $11.31^{\text {ns }}$ & $0.005^{\text {ns }}$ \\
Cationic composition of water & $(5)$ & $696.96^{* *}$ & $343.34^{* *}$ & $0.38^{*}$ \\
$\hat{y}_{1}$ & 1 & $232.26^{*}$ & $1139.05^{* *}$ & $0.017^{\text {ns }}$ \\
$\hat{y}_{2}$ & 1 & $521.45^{* *}$ & $272.70^{*}$ & $0.053^{\text {ns }}$ \\
$\hat{y}_{3}$ & 1 & $173.23^{*}$ & $46.07^{\text {ns }}$ & $0.011^{\text {ns }}$ \\
$\hat{y}_{4}$ & 1 & $789.12^{* *}$ & $1445.44^{* *}$ & $1.82^{* *}$ \\
$\hat{y}_{5}$ & 1 & $60.69^{*}$ & $191.67^{*}$ & $0.060^{\text {ns }}$ \\
Residual & 15 & 28.31 & 7.80 & 0.03 \\
CV $(\%)$ & & 17.27 & 12.00 & 13.83 \\
\hline
\end{tabular}

${ }^{\#} \mathrm{~S}_{1}=$ Control; $\mathrm{S}_{2}=\mathrm{Na}^{+} ; \mathrm{S}_{3}=\mathrm{Ca}^{2+} ; \mathrm{S}_{4}=\mathrm{Na}^{+}+\mathrm{Ca}^{2+} ; \mathrm{S}_{5}=\mathrm{K}^{+} ; \mathrm{S}_{6}=\mathrm{Na}^{+}+\mathrm{Ca}^{2+}+\mathrm{Mg}^{2+} ; \hat{\mathrm{y}}_{1}\left(\mathrm{~S}_{1} v s\right.$ $\left.\mathrm{S}_{2} ; \mathrm{S}_{3} ; \mathrm{S}_{4} ; \mathrm{S}_{5} ; \mathrm{S}_{6}\right) ; \hat{\mathrm{y}}_{2}\left(\mathrm{~S}_{2} v s \mathrm{~S}_{3}\right) ; \hat{\mathrm{y}}_{3}\left(\mathrm{~S}_{2} v s \mathrm{~S}_{6}\right) ; \hat{\mathrm{y}}_{4}\left(\mathrm{~S}_{2} v s \mathrm{~S}_{5}\right) ; \hat{\mathrm{y}}_{5}\left(\mathrm{~S}_{5} v s \mathrm{~S}_{2} ; \mathrm{S}_{3} ; \mathrm{S}_{4} ; \mathrm{S}_{6}\right) ; \mathrm{SV}-$ Source of variation; DF - Degree of freedom; CV - Coefficient of variation; $(*)$ and $(* *)$ Significant at 0.05 and 0.01 probability levels, respectively; (ns) Not significant. 
Water saturation deficit in the leaf blade was significantly influenced by the cationic composition of the irrigation water and, according to the means comparison test (Figure 1A), plants irrigated using water rich in $\mathrm{Na}^{+}\left(\mathrm{S}_{2}\right)$ and in $\mathrm{Na}^{+}+\mathrm{Ca}^{2+}\left(\mathrm{S}_{4}\right)$ had higher WSD, differing statistically from those in treatments $\mathrm{S}_{1}, \mathrm{~S}_{5}$ and $\mathrm{S}_{6}$. Plants subjected to irrigation with low-salinity water $\left(\mathrm{S}_{1}\right)$ showed the lowest WSD, but there was no significant difference in comparison to those irrigated with $\mathrm{K}^{+}$-rich water $\left(\mathrm{S}_{5}\right)$

From the results obtained for WSD at 90 DAS, it was possible to infer that the effect of salinity on castor bean is related to the presence of $\mathrm{Na}^{+}$in the irrigation water. Thus, this restriction in leaf water status, observed in the present study through the water saturation deficit in the leaf blade, may affect nutrient absorption by roots; consequently, plant growth and development are severely impaired.
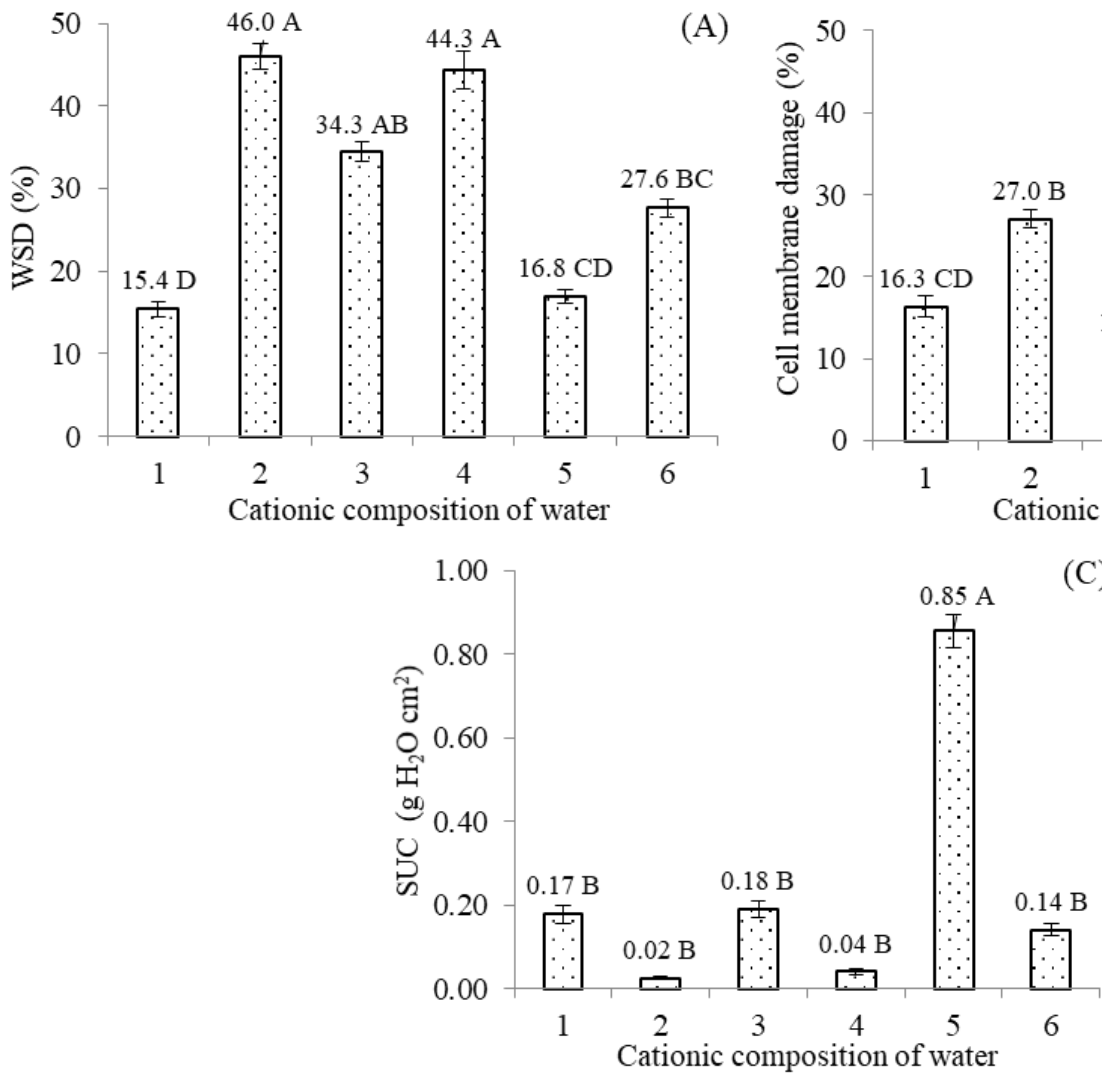

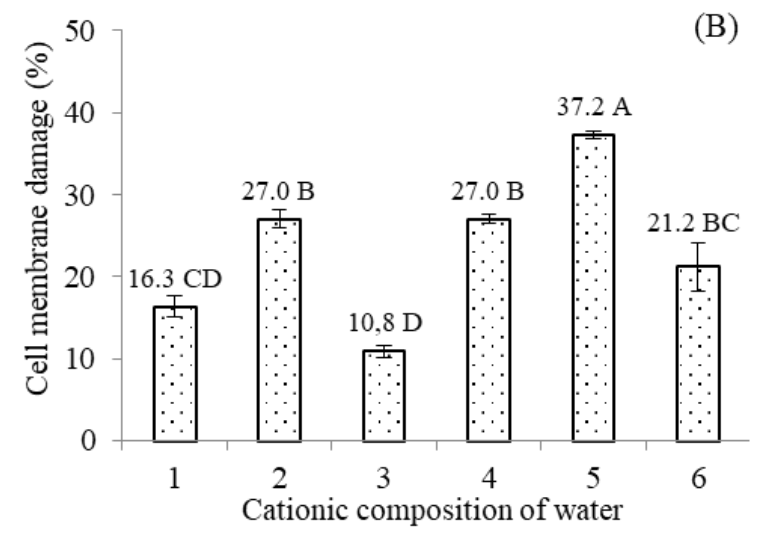

(C)

$1=$ Control; $2=\mathrm{Na}^{+} ; 3=\mathrm{Ca}^{2+} ; 4=\mathrm{Na}^{+}+\mathrm{Ca}^{2+} ; 5=\mathrm{K}^{+} ; 6=\mathrm{Na}^{+}+\mathrm{Ca}^{2+}+\mathrm{Mg}^{2+}$. Bars represent the standard error of the mean ( $\left.\mathrm{n}=4\right)$. Means with different letters differ by Tukey test $(\mathrm{p}<0.05)$.

Figure 1. Water saturation deficit - WSD (A), cell membrane damage - \%D (B) and leaf succulence - SUC (C) of castor bean cv. 'BRS Energia' as a function of irrigation water cationic composition, at 90 days after sowing.

According to the results of the means comparison test for cell membrane damage in castor bean at 90 DAS (Figure 1B), plants under irrigation with $\mathrm{K}^{+}$-rich water $\left(\mathrm{S}_{5}\right)$ had significantly higher $\% \mathrm{D}$ (37.2\%) compared to those irrigated with the other types of water. Figure $1 \mathrm{~B}$ also shows that $\% \mathrm{D}$ was significantly lower in plants irrigated with $\mathrm{Ca}^{2+}$-rich water, compared to the other treatments, except the control $\left(\mathrm{S}_{1}\right)$.

The means comparison test for leaf succulence (Figure 1C) at 90 DAS revealed that plants subjected to irrigation with $\mathrm{K}^{+}$-rich water $\left(\mathrm{S}_{5}\right)$ had higher SUC, differing statistically from those irrigated with low-salinity water $\left(\mathrm{S}_{1}\right)$ and water rich in $\mathrm{Na}^{+}\left(\mathrm{S}_{2}\right), \mathrm{Ca}^{2+}\left(\mathrm{S}_{3}\right), \mathrm{Na}^{+}+\mathrm{Ca}^{2+}\left(\mathrm{S}_{4}\right)$ and $\mathrm{Na}^{+}+$ $\mathrm{Ca}^{2+}+\mathrm{Mg}^{2+}\left(\mathrm{S}_{6}\right)$. Plants irrigated using water prepared with $\mathrm{Na}^{+}\left(\mathrm{S}_{2}\right)$ and $\mathrm{Na}^{+}+\mathrm{Ca}^{2+}\left(\mathrm{S}_{3}\right)$ showed the lowest values of leaf succulence at 90 DAS (Figure 1C). Different results were observed by Silva et al. (2009a), evaluating the accumulation of organic and inorganic solutes in jatropha (Jatropha curcas L.) subjected to $\mathrm{NaCl}$-induced salinity. These authors found that the highest leaf succulence was obtained at the highest $\mathrm{NaCl}$ concentration (100 $\mathrm{mmol} \mathrm{L}^{-1}$ ).

Based on the contrasts of means for water saturation deficit in the leaf blade of castor bean (Table 2), significant differences were observed in $\mathrm{S}_{1}$ vs $\mathrm{S}_{2}, \mathrm{~S}_{3}, \mathrm{~S}_{4}, \mathrm{~S}_{5}, \mathrm{~S}_{6} ; \mathrm{S}_{2}$ vs $\mathrm{S}_{3} ; \mathrm{S}_{2}$ vs $\mathrm{S}_{6} ; \mathrm{S}_{2}$ vs $\mathrm{S}_{5}$; and $\mathrm{S}_{5}$ vs $\mathrm{S}_{2}, \mathrm{~S}_{3}, \mathrm{~S}_{4}, \mathrm{~S}_{6}$. Based on the estimate of the mean (Table 3), the WSD of plants under ECw of $0.6 \mathrm{dS} \mathrm{m}^{-1}\left(\mathrm{~S}_{1}\right)$ was $18.48 \%$ lower than that found in 
plants irrigated with ECw of $4.5 \mathrm{dS} \mathrm{m}^{-1}$. By contrast, in plants irrigated with $\mathrm{S}_{2}$ water $\left(\mathrm{Na}^{+}\right)$, the WSD was on average $11.67,4.15$ and $21.25 \%$ higher compared to those irrigated using water prepared with $\mathrm{Ca}^{2+}$, $\mathrm{Ca}^{2+}+\mathrm{Na}^{+}$, and $\mathrm{K}^{+}$, respectively, demonstrating the more intense deleterious effect of $\mathrm{Na}^{+}$on WSD. The higher WSD in plants irrigated using $\mathrm{S}_{2}$ and $\mathrm{S}_{4}$ waters (Figure 1A) demonstrates a physiological response resulting from the adjustment of water potential by plants grown under high levels of salinity (GARCIA et al., 2009). When this occurs, the initial phase of osmotic adjustment is dehydration, i.e., there is a reduction in the water content due to the salt concentration in the medium (PRISCO, 1980).

According to the results presented above, plants irrigated using $\mathrm{K}^{+}$-rich water showed lower WSD compared to the other types of salts $\left(\mathrm{S}_{2} ; \mathrm{S}_{3} ; \mathrm{S}_{4}\right.$ and $S_{6}$ ), which may be related to the functions performed by $\mathrm{K}$ in plant metabolism, because this nutrient participates in the maintenance of ionic balance and cell turgor, through the control over stomatal opening and closing (GURGEL et al., 2010).

Table 3. Estimate of the mean for water saturation deficit (WSD), cell membrane damage (\%D) and leaf succulence (SUC) in castor bean cv. 'BRS Energia', irrigated with waters of different cationic compositions, at 90 days after sowing.

\begin{tabular}{cccc}
\hline \multirow{2}{*}{ Contrasts $^{\#}$} & \multicolumn{3}{c}{ Mean estimate } \\
\cline { 2 - 4 } & WSD (\%) & \%D & SUC $\left(\mathrm{g} \mathrm{H}_{2} \mathrm{O} \mathrm{cm}^{2}\right)$ \\
\hline$\hat{\mathrm{y}}_{1}$ & -18.48 & -8.34 & $\mathrm{~ns}$ \\
$\hat{\mathrm{y}}_{2}$ & 11.67 & 16.14 & $\mathrm{~ns}$ \\
$\hat{\mathrm{y}}_{3}$ & 4.15 & $\mathrm{~ns}$ & $\mathrm{~ns}$ \\
$\hat{\mathrm{y}}_{4}$ & 21.25 & -15.70 & -0.75 \\
$\hat{\mathrm{y}}_{5}$ & -7.73 & -4.35 & $\mathrm{~ns}$ \\
\hline
\end{tabular}

${ }_{\hat{\mathrm{y}}_{1}}\left(\mathrm{~S}_{1} v s \mathrm{~S}_{2} ; \mathrm{S}_{3} ; \mathrm{S}_{4} ; \mathrm{S}_{5} ; \mathrm{S}_{6}\right) ; \hat{\mathrm{y}}_{2}\left(\mathrm{~S}_{2} v s \mathrm{~S}_{3}\right) ; \hat{\mathrm{y}}_{3}\left(\mathrm{~S}_{2} v s \mathrm{~S}_{6}\right) ; \hat{\mathrm{y}}_{4}\left(\mathrm{~S}_{2} v s \mathrm{~S}_{5}\right) ; \hat{\mathrm{y}}_{5}\left(\mathrm{~S}_{5} v s \mathrm{~S}_{2} ; \mathrm{S}_{3} ; \mathrm{S}_{4} ; \mathrm{S}_{6}\right) ;$ $\mathrm{S}_{1}=$ Control; $\mathrm{S}_{2}=\mathrm{Na}^{+} ; \mathrm{S}_{3}=\mathrm{Ca}^{2+} ; \mathrm{S}_{4}=\mathrm{Na}^{+}+\mathrm{Ca}^{2+} ; \mathrm{S}_{5}=\mathrm{K}^{+} ; \mathrm{S}_{6}=\mathrm{Na}^{+}+\mathrm{Ca}^{2+}+\mathrm{Mg}^{2+} ;$ (ns) Not significant.

According to Table 3, which presents the contrasts of means for cell membrane damage, plants under irrigation with ECw of $0.6 \mathrm{dS} \mathrm{m}^{-1}\left(\mathrm{~S}_{1}\right)$ varied significantly compared to those under ECW of $4.5 \mathrm{dS}$ $\mathrm{m}^{-1}\left(\mathrm{~S}_{2} ; \mathrm{S}_{3} ; \mathrm{S}_{4} ; \mathrm{S}_{5}\right.$ and $\left.\mathrm{S}_{6}\right)$. Based on the estimate of the mean (Table 3 ), $\% \mathrm{D}$ was on average $8.34 \%$ lower in plants treated with low-salinity water $(0.6$ $\mathrm{dS} \mathrm{m}{ }^{-1}$ ) compared to those under ECw of $4.5 \mathrm{dS} \mathrm{m}^{-1}$ $\left(\mathrm{S}_{2} ; \mathrm{S}_{3} ; \mathrm{S}_{4} ; \mathrm{S}_{5} ; \mathrm{S}_{6}\right)$. Increase of the electrolyte concentration in leaf cells of plants grown under high salinity conditions may represent a mechanism to avoid dehydration of tissues, due to the reduction in the osmotic component of leaf water potential (FIOREZE et al., 2013).

A significant effect was observed on $\% \mathrm{D}$ $(\mathrm{p}<0.05)$ in the treatments $\mathrm{S}_{2} v s \mathrm{~S}_{3}, \mathrm{~S}_{2} v s \mathrm{~S}_{5}$ and $\mathrm{S}_{5} v s$ $\mathrm{S}_{2}, \mathrm{~S}_{3}, \mathrm{~S}_{4}, \mathrm{~S}_{6}$ and, according to the estimate of the mean (Table 3), \%D increased substantially in plants cultivated with $\mathrm{K}^{+}$-rich water $\left(\mathrm{S}_{5}\right)$, surpassing the mean by $15.70 \%$ compared to plants grown with $\mathrm{Na}^{+}$ -rich water $\left(\mathrm{S}_{2}\right)$. A reduction of $4.35 \%$ in $\% \mathrm{D}$ was found between plants subjected to $\mathrm{S}_{5}$ and those irrigated with waters containing the other cations $\left(\mathrm{S}_{2}\right.$; $\mathrm{S}_{3} ; \mathrm{S}_{4}$ and $\mathrm{S}_{6}$ ). Additionally, an increase of $16.14 \%$ in $\% \mathrm{D}$ was observed between plants subjected to $\mathrm{Na}^{+}$ -rich water $\left(\mathrm{S}_{2}\right)$ and those irrigated with $\mathrm{Ca}^{2+}$-rich water $\left(\mathrm{S}_{3}\right)$.

The lower $\% \mathrm{D}$ in plants irrigated with $\mathrm{Ca}^{2+}$ rich water $\left(\mathrm{S}_{3}\right)$ is explained by the functions performed by $\mathrm{Ca}$ in cell membrane integrity, since it is a constituent of cell walls (pectates), participating in the regulation of cell membrane function, besides activating various enzymatic systems (MENGEL; KIRKBY, 2000)

The summary of analysis of variance (Table 2) relative to the contrasts of means for leaf succulence shows that there was a significant effect only when plants were grown using $\mathrm{K}^{+}$-rich water $\left(\mathrm{S}_{5}\right)(\mathrm{p}<0.01)$, compared to those irrigated using $\mathrm{Na}^{+}$rich water $\left(\mathrm{S}_{2}\right)$. According to the estimate of the mean (Table 3), plants subjected to $\mathrm{S}_{5}$ showed an increase of $0.75 \mathrm{~g} \mathrm{H}_{2} \mathrm{O} \mathrm{cm}$ in SUC compared to those subjected to $\mathrm{S}_{2}$. This may result from the key role of $\mathrm{K}$ in osmotic regulation, maintaining turgor in guard cells by increasing their osmotic potential, which leads to absorption of water by these cells and adjacent cells, consequently generating increased turgor and stomatal opening (LANGER et al., 2004).

Based on the summary of analysis of variance for gas exchanges (Table 4), the irrigation water's cationic composition had a significant effect on the internal $\mathrm{CO}_{2}$ concentration $(\mathrm{Ci})$, stomatal conductance $(g s)$, transpiration $(E), \mathrm{CO}_{2}$ assimilation rate $(A)$, instantaneous carboxylation efficiency (CEi) and intrinsic water use efficiency (WUEi) of castor bean cv. 'BRS Energia' at 90 DAS. Sousa Júnior et al. (2017), evaluating the effects of water salinity and cationic composition (control; $\mathrm{Na}^{+} ; \mathrm{Ca}^{2+} ; \mathrm{K}^{+}$and $\mathrm{Na}^{+}+\mathrm{Ca}^{2+}+\mathrm{Mg}^{2+}$ ) on the gas exchanges of sunflower cv. BRS 324, observed a significant influence only on the stomatal conductance and $\mathrm{CO}_{2}$ assimilation rate. 
Table 4. Summary of analysis of variance for intercellular $\mathrm{CO}_{2}$ concentration $(\mathrm{Ci})$, stomatal conductance $(\mathrm{gs})$, transpiration $(E), \mathrm{CO}_{2}$ assimilation rate $(A)$, instantaneous carboxylation efficiency $(\mathrm{CEi})$ and intrinsic water use efficiency (WUEi) in castor bean cv. 'BRS Energia', irrigated with waters of different cationic compositions, at 90 days after sowing.

\begin{tabular}{cccccccc}
\hline \multirow{2}{*}{ VS/Contrasts } & \multirow{2}{*}{$\mathrm{DF}$} & \multicolumn{9}{c}{ Mean square } \\
\cline { 3 - 8 } & & $C i$ & $g s$ & $E$ & $A$ & CEi & WUEi \\
\hline Blocks & 3 & $2079.61^{\mathrm{ns}}$ & $0.002^{\text {ns }}$ & $0.08^{\text {ns }}$ & $4.00^{\text {ns }}$ & $0.0002^{\text {ns }}$ & $0.02^{\text {ns }}$ \\
Cationic composition of water & $(5)$ & $15022.66^{*}$ & $0.23^{* *}$ & $1.81^{*}$ & $121.12^{* *}$ & $0.003^{* *}$ & $21.88^{*}$ \\
$\hat{y}_{1}$ & 1 & $14740.83^{*}$ & $0.69^{* *}$ & $7.19^{* *}$ & $314.02^{* *}$ & $0.005^{*}$ & $27.41^{*}$ \\
$\hat{y}_{2}$ & 1 & $5408.00^{\text {ns }}$ & $0.0002^{\text {ns }}$ & $0.0006^{\text {ns }}$ & $1.86^{\text {ns }}$ & $0.000002^{\text {ns }}$ & $1.49^{\text {ns }}$ \\
$\hat{y}_{3}$ & 1 & $4004.16^{\text {ns }}$ & $0.0004^{\text {ns }}$ & $0.09^{\text {ns }}$ & $0.03^{\text {ns }}$ & $0.00001^{\text {ns }}$ & $0.05^{\text {ns }}$ \\
$\hat{y}_{4}$ & 1 & $42320.00^{*}$ & $0.50^{* *}$ & $1.75^{*}$ & $254.61^{*}$ & $0.009^{* *}$ & $59.44^{*}$ \\
$\hat{y}_{5}$ & 1 & $1487.81^{\text {ns }}$ & $0.03^{*}$ & $0.28^{\text {ns }}$ & $3.04^{\text {ns }}$ & $0.00001^{\text {ns }}$ & $6.31^{\text {ns }}$ \\
Residual & 15 & 3004.77 & 0.005 & 0.18 & 12.23 & 0.0002 & 4.23 \\
CV $(\%)$ & & 18.91 & 16.91 & 14.65 & 15.18 & 13.04 & 15.68 \\
\hline
\end{tabular}

${ }^{\#} \mathrm{~S}_{1}=$ Control; $\mathrm{S}_{2}=\mathrm{Na}^{+} ; \mathrm{S}_{3}=\mathrm{Ca}^{2+} ; \mathrm{S}_{4}=\mathrm{Na}^{+}+\mathrm{Ca}^{2+} ; \mathrm{S}_{5}=\mathrm{K}^{+} ; \mathrm{S}_{6}=\mathrm{Na}^{+}+\mathrm{Ca}^{2+}+\mathrm{Mg}^{2+} ; \hat{y}_{1}\left(\mathrm{~S}_{1} v s \mathrm{~S}_{2} ; \mathrm{S}_{3} ; \mathrm{S}_{4} ; \mathrm{S}_{5} ; \mathrm{S}_{6}\right) ; \hat{y}_{2}\left(\mathrm{~S}_{2}\right.$ vs $\left.\mathrm{S}_{3}\right) ; \hat{y}_{3}$ $\left(\mathrm{S}_{2} v s \mathrm{~S}_{6}\right) ; \hat{y}_{4}\left(\mathrm{~S}_{2} v s \mathrm{~S}_{5}\right) ; \hat{\mathrm{y}}_{5}\left(\mathrm{~S}_{5} v s \mathrm{~S}_{2} ; \mathrm{S}_{3} ; \mathrm{S}_{4} ; \mathrm{S}_{6}\right) ; \mathrm{SV}$ - Source of variation; DF - Degree of freedom; CV - Coefficient of variation; $\left({ }^{*}\right)$ and $(* *)$ Significant at 0.05 and 0.01 probability levels, respectively; (ns) Not significant.

According to the means comparison test for internal $\mathrm{CO}_{2}$ concentration (Figure 2A), plants irrigated using water containing $\mathrm{Na}^{+}+\mathrm{Ca}^{2+}$ showed the highest $\mathrm{C} i$, significantly differing from those subjected to low-salinity water $\left(\mathrm{S}_{1}\right)$ and those under irrigation with $\mathrm{K}^{+}$-rich water $\left(\mathrm{S}_{5}\right)$. However, no significant difference in $C i$ was found between plants irrigated using water containing $\mathrm{Na}^{+}\left(\mathrm{S}_{2}\right), \mathrm{Ca}^{2+}\left(\mathrm{S}_{3}\right)$, $\mathrm{Na}^{+}+\mathrm{Ca}^{2+}\left(\mathrm{S}_{4}\right)$ and $\mathrm{Na}^{+}+\mathrm{Ca}^{2+}+\mathrm{Mg}^{2+}\left(\mathrm{S}_{6}\right)$. Evaluating the physiology of castor bean plants cv. 'BRS Energia' under greenhouse conditions and different levels of irrigation water salinity, obtained with only $\mathrm{NaCl}\left(0.3\right.$ to $\left.3.9 \mathrm{dS} \mathrm{m} \mathrm{m}^{-1}\right)$, Soares et al. (2013) reported that irrigation water salinity causes an increment in their internal $\mathrm{CO}_{2}$ concentration.

The irrigation water's cationic composition had a significant influence on stomatal conductance (Figure 2B), and its values were higher in plants irrigated with low-salinity water $\left(\mathrm{S}_{1}\right)$ and $\mathrm{K}^{+}$-rich water $\left(\mathrm{S}_{5}\right)$ compared to those irrigated with water containing the other salts $\left(\mathrm{S}_{2}, \mathrm{~S}_{3}, \mathrm{~S}_{4}\right.$ and $\left.\mathrm{S}_{6}\right)$, which did not differ significantly. By comparing the means obtained in the different treatments (Figure 2B), it is possible to note that, except for plants subjected to irrigation with $\mathrm{K}^{+}$-rich water $\left(\mathrm{S}_{5}\right)$, the deleterious effect of salinity on castor bean stomatal conductance was similar for all treatments $\left(\mathrm{Na}^{+}\right.$; $\left.\mathrm{Ca}^{2+} ; \mathrm{Na}^{+}+\mathrm{Ca}^{2+} ; \mathrm{Na}^{+}+\mathrm{Ca}^{2+}+\mathrm{Mg}^{2+}\right)$, despite the variation in the irrigation water's cationic composition.

Castor bean transpiration was also significantly affected $(\mathrm{p}<0.05)$ by the variation in the irrigation water's cationic composition (Table 4) and, according to the means comparison test (Figure 2C), $E$ was statistically higher in the low-salinity water treatment $\left(\mathrm{S}_{1}\right)$ than in the others, except for $\mathrm{S}_{5}$. However, castor bean plants irrigated with high- salinity water did not differ statistically, regardless of cationic composition. These results corroborate those obtained by Sousa Júnior et al. (2017), who observed that, under saline conditions, leaf transpiration in sunflower cv. BRS 324 shows a similar behavior with the variation in irrigation water electrical conductivity, regardless of the composition in terms of salts.

For the $\mathrm{CO}_{2}$ assimilation rate, the means comparison test (Figure 2D) shows that plants irrigated with low-salinity water $\left(\mathrm{S}_{1}\right)$ and $\mathrm{K}^{+}$-rich water $\left(\mathrm{S}_{5}\right)$ were statistically superior to those subjected to the other cationic combinations $\left(\mathrm{S}_{2}, \mathrm{~S}_{3}\right.$, $\mathrm{S}_{4}$ and $\mathrm{S}_{6}$ ), which did not differ significantly from one another. Plants irrigated with $\mathrm{K}^{+}$-rich water $\left(\mathrm{S}_{5}\right)$ and low-salinity water $\left(\mathrm{S}_{1}\right)$ showed the highest

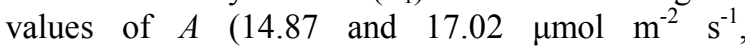
respectively) (Figure 2D). Such behavior confirms the data obtained for stomatal conductance (Figure 2B) and transpiration (Figure 2C) and suggests that the reduction in the photosynthetic rate may result from partial stomatal closure associated with the osmotic effects of salinity and ionic toxicity on the plant metabolism (BEZERRA et al., 2005).

According to the results of the means comparison test for instantaneous carboxylation efficiency (Figure 2E), plants irrigated with lowsalinity water $\left(\mathrm{S}_{1}\right)$ differed significantly $(\mathrm{p}<0.01)$ from those irrigated with waters of high salinity level and different ionic compositions $\left(\mathrm{S}_{2}, \mathrm{~S}_{3}\right.$ and $\left.\mathrm{S}_{4}\right)$. For $\mathrm{CEi}$, plants in the $\mathrm{S}_{5}$ treatment differed significantly from those irrigated with saline water containing $\mathrm{Na}^{+}$ $\left(\mathrm{S}_{2}\right), \mathrm{Ca}^{2+}\left(\mathrm{S}_{3}\right), \mathrm{Na}^{+}+\mathrm{Ca}^{2+}\left(\mathrm{S}_{4}\right)$ and $\mathrm{Na}^{+}+\mathrm{Ca}^{2+}+\mathrm{Mg}^{2+}$ $\left(\mathrm{S}_{6}\right)$. No significant difference was observed among the data obtained with the different cationic compositions $\left(\mathrm{S}_{2}, \mathrm{~S}_{3}, \mathrm{~S}_{4}\right.$ and $\left.\mathrm{S}_{6}\right)$. 

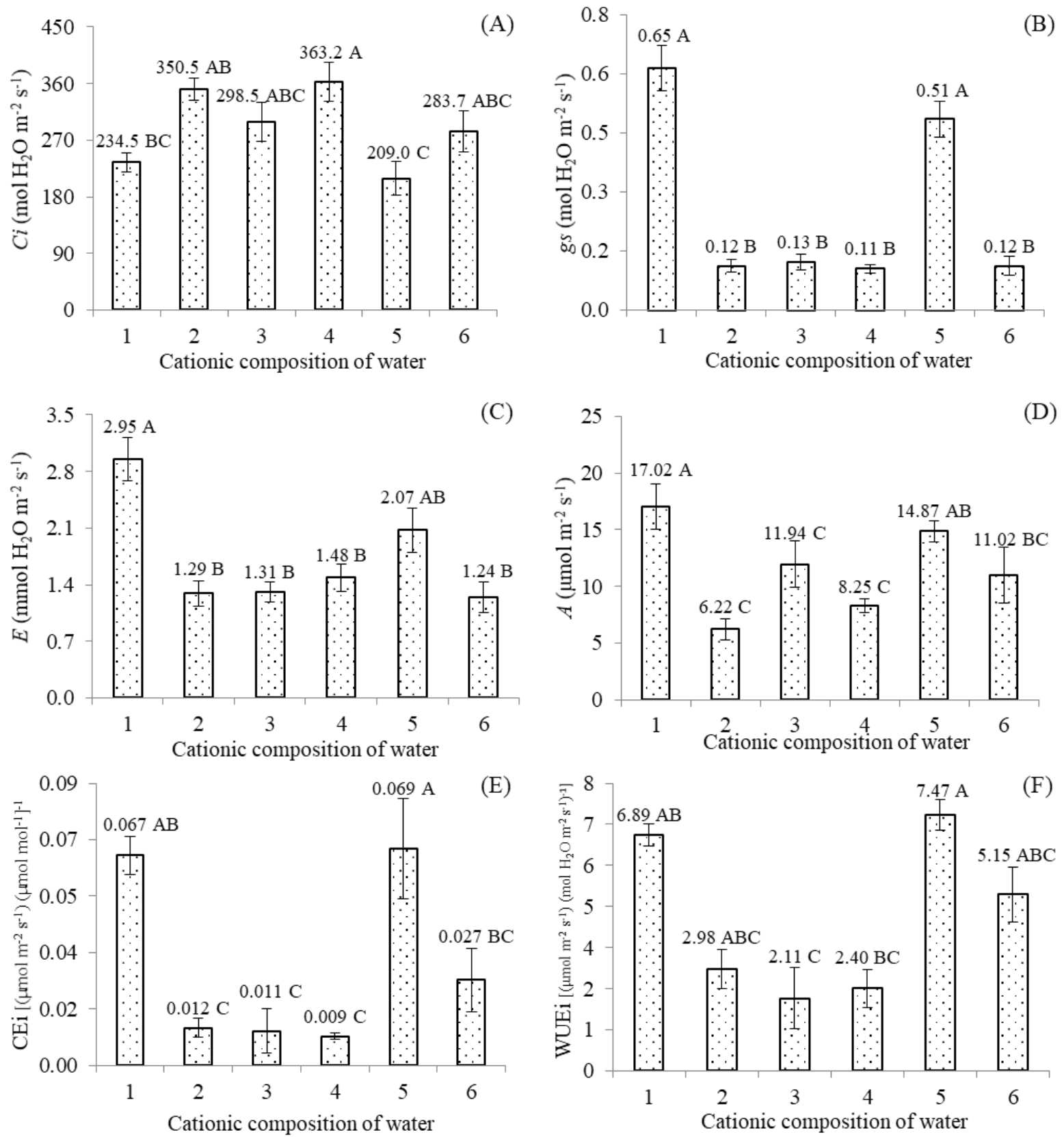

$1=$ Control; $2=\mathrm{Na}_{+} ; 3=\mathrm{Ca}_{2+} ; 4=\mathrm{Na}^{+} \mathrm{Ca}^{2+} ; 5=\mathrm{K}^{+} ; 6=\mathrm{Na}^{+}+\mathrm{Ca}^{2+}+\mathrm{Mg}^{2+}$. Bars represent the standard error of the mean (n=4). Means with different letters differ by Tukey test $(\mathrm{p}<0.05)$.

Figure 2. Intercellular $\mathrm{CO}_{2}$ concentration - $\mathrm{Ci}(\mathrm{A})$, stomatal conductance - $g s(\mathrm{~B})$, transpiration - $E(\mathrm{C}), \mathrm{CO}_{2}$ assimilation rate - $A(\mathrm{D})$, instantaneous carboxylation efficiency - CEi (E) and intrinsic water use efficiency - WUEi (F) of castor bean cv. 'BRS Energia', as a function of irrigation water cationic composition.

Intrinsic water use efficiency was significantly influenced by the cationic composition of irrigation water at 90 DAS. According to the means comparison test (Figure 2F), the WUEi of plants irrigated using water of the lowest salinity level $\left(\mathrm{S}_{1}\right)$ differed significantly only from that of plants subjected to $\mathrm{Ca}^{2+}$-rich water $\left(\mathrm{S}_{3}\right)$. However, no significant difference was observed in WUEi between plants subjected to $\mathrm{S}_{5}$ and those in the treatments $\mathrm{S}_{2}$ and $\mathrm{S}_{6}$. In addition, plants in the treatments $\mathrm{S}_{1}$ and $\mathrm{S}_{5}$ showed the highest values of intrinsic water use efficiency $[6.89$ and $\left.7.47\left(\mu \mathrm{mol} \mathrm{m} \mathrm{m}^{-2} \mathrm{~s}^{-1}\right)\left(\mathrm{mol} \mathrm{H} \mathrm{O} \mathrm{m}^{-2} \mathrm{~s}^{-1}\right)^{-1}\right]$, respectively, compared to the other treatments $\left(\mathrm{S}_{2}, \mathrm{~S}_{3}, \mathrm{~S}_{4}\right.$ and $\left.\mathrm{S}_{6}\right)$.

According to the summary of analysis of variance for the contrasts of means (Table 4), the irrigation water's cationic composition had a significant effect on all the variables studied $(g s, E$, $A, C i, \mathrm{CEi}$ and WUEi), comparing plants subjected to the lowest level of electrical conductivity $\left(0.6 \mathrm{dS} \mathrm{m}^{-1}\right)$ and those under ECw of $4.5 \mathrm{dS} \mathrm{m}^{-1}\left(\mathrm{~S}_{2}\right.$, $\mathrm{S}_{3}, \mathrm{~S}_{4}, \mathrm{~S}_{5}$ and $\mathrm{S}_{6}$ ). Based on the estimate of the mean (Table 5), gs, E, A, CEi and WUEi increased by 0.45 $\mathrm{mol} \mathrm{H}_{2} \mathrm{O} \quad \mathrm{m}^{-2} \mathrm{~s}^{-1}, \quad 1.46$ mol $\mathrm{H}_{2} \mathrm{O} \quad \mathrm{m}^{-2} \mathrm{~s}^{-1}$, 
$9.70 \mu \mathrm{mol} \quad \mathrm{m}^{-2} \quad \mathrm{~s}^{-1}, \quad 0.041 \quad\left[\left(\mu \mathrm{mol} \quad \mathrm{m}^{-2} \mathrm{~s}^{-1}\right)\right.$ $\left.\left(\mu \mathrm{mol} \mathrm{mol}^{-1}\right)^{-1}\right]$ and $2.86 \quad\left(\mu \mathrm{mol} \quad \mathrm{m}^{-2} \mathrm{~s}^{-1}\right)$ $\left(\mathrm{mol} \mathrm{H} \mathrm{O} \mathrm{m}^{-2} \mathrm{~s}^{-1}\right)^{-1}$ between plants under ECw levels of $0.6 \mathrm{dS} \mathrm{m} \mathrm{m}^{-1}$ and $4.5 \mathrm{dS} \mathrm{m}^{-1}$. The reduction of gas exchanges ( $E, A, \mathrm{CEi}$ and WUEi) in plants subjected to the highest level of salinity $\left(\mathrm{S}_{2}, \mathrm{~S}_{3}, \mathrm{~S}_{4}, \mathrm{~S}_{5}\right.$ and $\left.\mathrm{S}_{6}\right)$ may be related to the change in the osmotic potential and, consequently, to the reduction of water availability in their tissues and low capacity for osmotic adjustment, due to the increase in salt concentration (SILVA et al., 2011).

Table 5. Estimate of mean for stomatal conductance $(g s)$, transpiration $(E), \mathrm{CO}_{2}$ assimilation rate $(A)$, intercellular $\mathrm{CO}_{2}$ concentration $(\mathrm{Ci})$, instantaneous carboxylation efficiency (CEi) and intrinsic water use efficiency (WUEi) in castor bean cv. 'BRS Energia', irrigated with waters of different cationic compositions, at 90 days after sowing.

\begin{tabular}{|c|c|c|c|c|c|c|}
\hline \multirow{2}{*}{ Contrasts $^{\#}$} & \multicolumn{6}{|c|}{ Mean estimate } \\
\hline & $g s$ & $E$ & $A$ & $\mathrm{Ci}$ & $\mathrm{CEi}$ & WUEi \\
\hline$\hat{\mathrm{y}}_{1}$ & 0.45 & 1.46 & 9.70 & -66.50 & 0.041 & 2.86 \\
\hline$\hat{\mathrm{y}}_{2}$ & $\mathrm{~ns}$ & ns & ns & ns & ns & ns \\
\hline$\hat{\mathrm{y}}_{3}$ & ns & ns & ns & ns & ns & ns \\
\hline$\hat{\mathrm{y}}_{4}$ & -0.39 & -0.74 & -8.92 & 115.00 & -0.054 & -4.31 \\
\hline$\hat{\mathrm{y}}_{5}$ & ns & ns & ns & ns & ns & ns \\
\hline
\end{tabular}

${ }^{\#} \hat{\mathrm{y}}_{1}\left(\mathrm{~S}_{1} v s \mathrm{~S} \mathrm{~S}_{2} ; \mathrm{S}_{3} ; \mathrm{S}_{4} ; \mathrm{S}_{5} ; \mathrm{S}_{6}\right) ; \hat{\mathrm{y}}_{2}\left(\mathrm{~S}_{2} v s \mathrm{~S}_{3}\right) ; \hat{\mathrm{y}}_{3}\left(\mathrm{~S}_{2} v s \mathrm{~S} \mathrm{~S}_{6}\right) ; \hat{\mathrm{y}}_{4}\left(\mathrm{~S}_{2}\right.$ vs $\left.\mathrm{S}_{5}\right) ; \hat{\mathrm{y}}_{5}\left(\mathrm{~S}_{5} v s \mathrm{~S}_{2} ; \mathrm{S}_{3} ; \mathrm{S}_{4} ; \mathrm{S}_{6}\right) ; \mathrm{S}_{1}=$ Control; $\mathrm{S}_{2}=\mathrm{Na}^{+} ; \mathrm{S}_{3}=\mathrm{Ca}^{2+}$; $\mathrm{S}_{4}=\mathrm{Na}^{+}+\mathrm{Ca}^{2+} ; \mathrm{S}_{5}=\mathrm{K}^{+} ; \mathrm{S}_{6}=\mathrm{Na}^{+}+\mathrm{Ca}^{2+}+\mathrm{Mg}^{2+} ;$ (ns) Not significant.

In relation to $C i$, there was an increase of

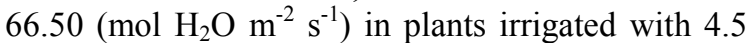
$\mathrm{dS} \mathrm{m} \mathrm{m}^{-1}$ water, compared to those under ECw of 0.6 $\mathrm{dS} \mathrm{m}{ }^{-1}$. It should be highlighted that a higher internal $\mathrm{CO}_{2}$ concentration $\left(\mathrm{S}_{2}, \mathrm{~S}_{3}, \mathrm{~S}_{4}\right.$ and $\left.\mathrm{S}_{6}\right)$ means that the $\mathrm{C}$ entering leaf mesophyll cells was not being metabolized by the photosynthetic apparatus, due to the salt stress condition to which these plants were exposed. Such increase in intercellular $\mathrm{CO}_{2}$ concentration is an indication that $\mathrm{CO}_{2}$ acquisition by the plant was not restricted. However, when the $\mathrm{CO}_{2}$ reached mesophyll cells, the fixation process during the carboxylation phase was compromised (HABERMANN et al., 2003), which may be linked to the degradation of the photosynthetic apparatus in response to leaf tissue senescence, resulting from the stress caused by excess salts (SILVA et al., 2013).

Castor bean plants irrigated with $\mathrm{K}^{+}$-rich water were superior to those irrigated using $\mathrm{Na}^{+}$-rich water $\left(\mathrm{S}_{2}\right)$, with respect to $g S, E, A, \mathrm{CEi}$ and WUEi, which had mean values of $0.39 \mathrm{~mol} \mathrm{H}_{2} \mathrm{O} \mathrm{m}^{-2} \mathrm{~s}^{-1}, 0.74$ $\mathrm{mol} \mathrm{H} \mathrm{O} \mathrm{m}^{-2} \mathrm{~s}^{-1}, 8.92 \mu \mathrm{mol} \mathrm{m} \mathrm{m}^{-2} \mathrm{~s}^{-1}, 0.054\left(\mu \mathrm{mol} \mathrm{m} \mathrm{m}^{-2} \mathrm{~s}\right.$ $\left.{ }^{-1}\right)\left(\mu \mathrm{mol} \mathrm{mol}^{-1}\right)^{-1}$ and $4.31\left(\mu \mathrm{mol} \mathrm{m} \mathrm{s}^{-1}\right)\left(\mathrm{mol} \mathrm{H}_{2} \mathrm{O}\right.$ $\left.\mathrm{m}^{-2} \mathrm{~s}^{-1}\right)^{-1}$, respectively. However, $C i$ decreased by $115 \mathrm{~mol} \mathrm{H}_{2} \mathrm{O} \mathrm{m}^{-2} \mathrm{~s}^{-1}$ between plants in the $\mathrm{S}_{5}$ treatment and those irrigated using $\mathrm{Na}^{+}$-rich water $\left(\mathrm{S}_{2}\right)$. This result is explained by the importance of $\mathrm{K}$ in plant metabolism, participating in various physiological processes, including cell expansion, enzymatic activation, stomatal opening and closing, and maintenance of turgor pressure (WHITE; KARLEY, 2010). Additionally, $K$ acts in the regulation of cell osmotic potential and the control of ionic homeostasis, osmoregulation, protein metabolism, enzymatic activity, polarization of membranes, and several metabolic processes (SCHACHTMAN; SHIN, 2007; BERNARDI et al., 2010).

\section{CONCLUSIONS}

The higher leaf succulence associated with lower water saturation deficit is an indication of tolerance to salt stress in castor bean irrigated with $\mathrm{K}^{+}$-rich water. The presence of $\mathrm{Na}^{+}$salts in irrigation water leads to the highest water saturation deficit in the leaf blade of castor bean cv. 'BRS Energia'. The lowest damage to cell membranes is obtained in plants irrigated using $\mathrm{Ca}^{2+}$-rich water. The deleterious effect of salt stress on castor bean gas exchanges depends on cationic composition of the irrigation water and occurs in the following order: $\mathrm{Na}^{+}>\mathrm{Na}^{+}+\mathrm{Ca}^{2+}>\mathrm{Ca}^{2+}>\mathrm{Na}^{+}+\mathrm{Ca}^{2+}+\mathrm{Mg}^{2+}>\mathrm{K}^{+}$.

\section{ACKNOWLEDGMENTS}

To the National Post-doctoral Program (PNPD/CAPES/UFCG), for granting the scholarship to the first author, and to the National Institute of Science and Technology in Salinity - INCTSal, for funding the project.

\section{REFERENCES}

AHMED, B. A. O.; MORITANI, I. S. Effect of saline water irrigation and manure application on the available water content, soil salinity, and growth of wheat. Agricultural Water Management, v. 97, n. 1, p. $165-170,2010$.

ALVES, A. N. et al. Uso de águas salinas e adubação nitrogenada no cultivo da mamoneira BRS -Energia. Revista Brasileira de Agricultura Irrigada, v. 6, n. 2, p. 151-163, 2012.

AYRES, R. S.; WESTCOT, D. W. A qualidade da água na agricultura. 2. ed. Campina Grande, $\mathrm{PB}$ : 
UFPB. 1999. 153 p.

BERNARDI, A. C. C. et al. Comparação de técnicas analíticas para a extração de potássio de amostras de tecido vegetal com água e soluções ácidas concentradas e diluída. Eclética Química, v. 35, n. 2, p. 45-49, 2010.

BEZERRA, M. A. et al. Crescimento e fotossíntese de plantas jovens de cajueiro anão-precoce sob estresse salino. Revista Brasileira de Engenharia Agrícola e Ambiental, v. 9, sup., p. 90-94, 2005.

CLAESSEN, M. E. C. Manual de métodos de análise de solo. 2. ed. rev. atual. Rio de Janeiro, RJ: Embrapa-CNPS, 1997. 212 p. (Embrapa-CNPS. Documentos, 1).

COMPANHIA NACIONAL

DE ABASTECIMENTO - CONAB. Acompanhamento da safra brasileira de grãos. Brasília: Safra 2017/2018. Disponível em: <www.conab.gov.br/info -agro/safras/graos/boletim-da-safra-de-graos $>$.

Acesso em: 03 set. 2018.

FERREIRA, D. F. Sisvar: A computer statistical analysis system. Ciência e Agrotecnologia, v. 35, n. 6, p. 1039-1042, 2011.

FIOREZE, S. L. et al. Fisiologia e produção da soja tratada com cinetina e cálcio sob déficit hídrico e sombreamento. Pesquisa Agropecuária Brasileira, v. 48, n. 11 , p. 1432-1439, 2013.

GARCIA, G. O. et al. Estresse hídrico e salino na produção relativa e potencial de água na folha do feijoeiro. Irriga, v. 14, n. 4, p. 470-480, 2009.

GURGEL, M. T. et al. Crescimento de meloeiro sob estresse salino e doses de potássio. Revista Brasileira de Engenharia Agrícola e Ambiental, v. 14, n. 1, p. 3-10, 2010.

HABERMANN, G. et al. $\mathrm{CO}_{2}$ assimilation, photosynthetic light response curves, and water relations of 'Pêra' sweet orange plants infected with Xylella fastidious. Brazilian Journal of Plant Physiology, v. 15, n. 2, p. 79-87, 2003.

LANGER, K. et al. The poplar $\mathrm{K}^{+}$channel KPT1 is associated with $\mathrm{K}^{+}$uptake during stomatal opening and bud development. The Plant Journal, v. 37, n. 6, p. $828-838,2004$.

LIMA, G. S. et al. Crescimento, teor de sódio, cloro e relação iônica na mamoneira sob estresse salino e adubação nitrogenada. Comunicata Scientiae, v. 6, n. 2, p. 212-223, 2015a.

LIMA, G. S. et al. Water relations and gas exchange in castor bean irrigated with saline water of distinct cationic nature. African Journal of Agricultural Research, v. 10, n. 13, p. 1581-1594, 2015b.

MANTOVANI, A. A method to improve leaf succulence quantification. Brazilian Archives of Biology and Technology, v. 42, n. 1, p. 9-14, 1999.

MENGEL, K.; KIRKBY, E. A. Princípios de nutrición vegetal. Basel: International Potash Institute, 2000. 692 p.

NEVES, A. L. R. et al. Trocas gasosas e teores de minerais no feijão-de-corda irrigado com água salina em diferentes estádios. Revista Brasileira de Engenharia Agrícola e Ambiental, v. 13, sup., p. 873-881, 2009.

NOBRE, R. G. et al. Emergência, crescimento e produção da mamoneira sob estresse salino e adubação nitrogenada. Revista Ciência Agronômica, v. 44, n. 1, p. 76-85, 2013.

NOBRE, R. G. et al. Produção de girassol sob estresse salino e adubação nitrogenada. Revista Brasileira de Ciência do Solo, v. 35, n. 3, p. 929937, 2011

NOVAIS, R. F.; NEVES, J. C. L.; BARROS, N. F. Ensaio em ambiente controlado. In: OLIVEIRA, A. J. et al. (Eds.). Métodos de pesquisa em fertilidade do solo. Brasília: Embrapa SEA, 1991. p. 189-253.

PRISCO, J. T. Alguns aspectos da fisiologia do estresse salino. Revista Brasileira de Botânica, v. 3, n. 1-2, p. 85-94, 1980.

RICHARDS, L. A. Diagnosis and improvement of saline and alkali soils. Agriculture Handbook No. 60, Washington: USDA, Department of Agriculture, 1954. $160 \mathrm{p}$.

RODRIGUES, L. N. et al. Crescimento e produção de bagas da mamoneira irrigada com água residuária doméstica. Revista Brasileira de Engenharia Agrícola e Ambiental, v. 13, sup., p. 825-835, 2009.

SANTOS, J. B. dos et al. Comportamento morfofisiológico da mamoneira BRS Energia submetida à irrigação com água salina. Revista Brasileira de Engenharia Agrícola e Ambiental, v. 17, n. 2, p. 145-152, 2013.

SCHACHTMAN, D. P.; SHIN, R. Nutrient sensing and signaling: NPKS. Annual Review of Plant Biology, v. 58, n. 1, p. 47-69, 2007.

SCOTTI-CAMPOS, P. et al. Physiological responses and membrane integrity in three Vigna genotypes with contrasting drought tolerance. Emirates 
Journal of Food and Agriculture, v. 25, n. 12, p. 1002-1013, 2013.

SILVA, A. R. A. da et al. Trocas gasosas em plantas de girassol submetidas à deficiência hídrica em diferentes estádios fenológicos. Revista Ciência Agronômica, v. 44, n. 1, p. 86-93, 2013.

SILVA, E. N. da et al. Contribuição de solutos orgânicos e inorgânicos no ajustamento osmótico de pinhão-manso submetido à salinidade. Pesquisa Agropecuária Brasileira, v. 44, n. 5, p. 437-445, 2009a.

SILVA, F. L. B. da et al. Interação entre salinidade e biofertilizante bovino na cultura do feijão-de-corda.

Revista Brasileira de Engenharia Agrícola e Ambiental, v. 15, n. 4, p. 383-389, 2011.

SILVA, L. A. et al. Mecanismos fisiológicos de percepção do estresse salino de híbridos de porta enxertos citros em cultivo hidropônico. Revista Brasileira de Engenharia Agrícola e Ambiental, v. 18 , sup., p. 1-7, 2014.

SILVA, S. M. et al. Dotações hídricas em densidades de plantas na cultura da mamoneira cv. BRS Energia. Revista Brasileira de Ciências Agrárias, v. 4, n. 3, p. 338-348, 2009b.

SOARES, L. A. A. et al. Componentes de crescimento da mamoneira cultivada com águas salinas e doses de nitrogênio. Irriga, v. 1, n. 1, p. 4054, 2012.

SOARES, L. A. A. et al. Fisiologia e acúmulo de fitomassa pela mamoneira submetida a estresse salino e adubação nitrogenada. Revista Verde de Desenvolvimento Sustentável, v. 8, n. 1, p. 247256, 2013.

SOUSA JÚNIOR, J. R. de. Gas exchange and production of sunflower (Helianthus annuus L.) irrigated with water of different salinity, cationic nature and nitrogen doses. Australian Journal of Crop Science, v. 11, n. 3, p. 300-307, 2017.

WHITE, P.J.; KARLEY, A. J. Potassium. In: HELL R.; MENDEL R. R. (Eds.). Cell biology of metals and nutrients. Heidelberg: Springer, 2010. v. 1, cap. 8, p. 199-224. 